\title{
Subsurface profiling of granite pluton using microtremor method: southern Aravalli, Gujarat, India
}

\author{
Aditya U. Joshi ${ }^{1}$ - Dhananjay A. Sant ${ }^{1}$ Imtiyaz A. Parvez ${ }^{2}$ Govindan Rangarajan ${ }^{3}$. \\ Manoj A. Limaye ${ }^{1} \cdot$ Soumyajit Mukherjee $^{4} \cdot$ Mitesh J. Charola $^{1}$. \\ Meghnath N. Bhatt ${ }^{1} \cdot$ Sagar P. Mistry ${ }^{1}$
}

Received: 8 December 2016 / Accepted: 15 April 2017 / Published online: 27 April 2017

(C) Springer-Verlag Berlin Heidelberg 2017

\begin{abstract}
We report, using the microtremor method, a subsurface granitic pluton underneath the Narukot Dome and in its western extension along a WNW profile, in proximity of eastern fringe of Cambay Rift, India. The dome and its extension is a part of the Champaner Group of rocks belonging to the Mesoproterozoic Aravalli Supergroup. The present finding elucidates development of an asymmetric double plunge along Narukot Dome. Microtremor measurements at 32 sites were carried out along the axial trace $\left(\mathrm{N} 95^{\circ}\right)$ of the dome. Fourier amplitude spectral studies were applied to obtain the ratio between the horizontal and vertical components of persisting Rayleigh waves as local ambient noise. Fundamental resonant frequencies with amplitude $\geq 1$-sigma for each site are considered to distinguish rheological boundary. Two distinct rheological boundaries are identified based on frequency ranges determined in the terrain: (1) $0.2219-10.364 \mathrm{~Hz}$ recorded at 31 stations identified as the Champaner metasediment and granite boundary, and (2) $10.902-27.1119 \mathrm{~Hz}$ recorded at
\end{abstract}

Soumyajit Mukherjee

soumyajitm@gmail.com

Aditya U. Joshi

adityaujoshi@gmail.com

Dhananjay A. Sant

sant.dhananjay-geology@msubaroad.ac.in

Imtiyaz A. Parvez

parvez@csir4pi.in

Govindan Rangarajan

rangaraj@math.iisc.ernet.in

Manoj A. Limaye

limaye.manoj-geology@msubaroda.ac.in

Mitesh J. Charola

charolamitesh@gmail.com
22 stations identified as the phyllite and quartzite boundary. The proposed equation describing frequency-depth relationship between granite and overlaying regolith matches with those already published in the literature. The morphology of granite pluton highlights the rootless character of Champaner Group showing sharp discordance with granitic pluton. The findings of manifestation of pluton at a shallower depth imply a steep easterly plunge within the Champaner metasediments, whereas signature of pluton at a deeper level implies a gentle westerly plunge. The present method enables to assess how granite emplacement influences the surface structure.

Keywords Microtremor · H/V spectral analysis · Granite pluton $\cdot$ Champaner group $\cdot$ Aravalli

Meghnath N. Bhatt

meghrajnath@gmail.com

Sagar P. Mistry

mistrusagar24@gmail.com

1 Department of Geology, Faculty of Science, The Maharaja Sayajirao University of Baroda, Vadodara, Gujarat 390002 , India

2 CSIR Fourth Paradigm Institute (Formerly CSIR Centre for Mathematical Modeling and Computer Simulation), NAL Belur Campus, Bengaluru, Karnataka 560 037, India

3 Department of Mathematics, Indian Institute of Science Bangalore, Bengaluru, Karnataka 560 012, India

4 Department of Earth Sciences, Indian Institute of Technology Bombay, Powai, Mumbai, Maharashtra 400 076, India 


\section{Introduction}

Neoproterozoic granites in this study popularly referred to as Godhra granite, constitute a part of major syn- to post-orogenic granitic phase of southeastern Aravalli domain, western India. The Godhra granite have emplaced regionally along NW-SE trend, which splayed further SE-producing sporadic plutons (Mamtani et al. 2001; Mamtani and Greiling 2005). Emplacements of these plutons have locally deformed as well as generated contact metamorphism within Mesoproterozoic Champaner metasediments (Mamtani et al. 2001; Das et al. 2009; Limaye and Joshi 2016). The role of sporadic plutonic activity, however, induced structural complexity (Jambusaria and Merh 1967; Srikarni and Das 1996; Karanth and Das 2000). Doubly plunging Narukot dome, a part of Champaner Group forming southern extension of Aravallis in Gujarat, is one such feature that gives an opportunity to study the relationship of pluton and associated deformation. Deciphering subsurface morphology of pluton becomes vital.

Globally, the plutons are understood emplacing country rock with several geometric shapes, viz. circular, thick disk, sheet-like, hockey puck, flat-floored, wedge-shaped and many other discrete forms (McSween and Harvey 1997; Benn et al. 1998; Vigneresse et al. 1999) that in turn depend on the heterogeneity of magmatic activity, depth, and their degree of isolation as well as volume, strength and density difference between the plutonic melt and the country rocks (Bott 1955; Pitcher 1979; Vigneresse 1995; Benn et al. 1998; Stevenson et al. 2006; Cruden 2008). Several geophysical methods are deployed to study plutons, viz. gravity (Bott 1955; Vigneresse 1990; Singh et al. 2004; Rao et al. 2006; Cruden 2008; Singh et al. 2014), magnetic (Mamtani and Greiling 2005); aeromagnetic (Sahu 2012) magnetotelluric (Sastry et al. 2008); deep resistivity soundings (Singh et al. 2008); and deep seismic methods (Kaila et al. 1981; Dixit et al. 2010).

We apply a cost-effective microtremor technique to map subsurface pluton covering a large area at a prerequisite terrain-specific resolution from $250 \mathrm{~m}$ to $1 \mathrm{~km}$ interval. The assessment was quicker than the conventional indirect methods. The microtremor method has been used successfully to map subsurface rheological boundaries based on strong acoustic impedance along contrasting density at sediment/rock interphases at shallow depths and across fault zones (Kanai 1957; Yamanaka et al. 1994; Ibs-Vonseht and Wohlenberg 1999; Delgado et al. 2000a, b; Parolai et al. 2002; Garcia-Jerez et al. 2006; Guéguen et al. 2006; Zhao et al. 2007; Dinesh et al. 2010; Rošer and Gosar 2010; Sukumaran et al. 2011; Paudyal et al. 2013).

The present maiden attempt is to record a shallow seismic profile along doubly plunging Narukot dome and its western extension incorporating both microtremor method and field evidences. This enabled us (1) to delineate morphology of an independent granite pluton underneath the Narukot dome, (2) to determine the thickness of the Mn-bearing rocks of the Champaner Group, and (3) to infer implication towards syntectonic deformation of the Champaner Group.

\section{Geology and structures}

The vast area $\mathrm{E}$ and $\mathrm{SE}$ of Narukot dome has a rolling topography with isolated highs that exposes Jambughoda Granite $(1050 \pm 50$ Ma: Sm-Nd method, Shivkumar et al. 1993); Chhota Udepur Granite (1168 \pm 30 Ma: $\mathrm{Rb}-\mathrm{Sr}$ method, Srimal and Das 1998) and Godhra Granite $(950 \mathrm{Ma}, \mathrm{Rb}-\mathrm{Sr}$ method assuming an initial $\mathrm{Sr}$ ratio of 0.700, Crawford 1975; Rb-Sr method $955 \pm 20 \mathrm{Ma}$, Gopalan et al. 1979; Rb-Sr method $938.8 \pm 20 \mathrm{Ma}$, Srimal and Das 1998; Rb-Sr method $965 \pm 40$ Ma, Goyal et al. 2001) (Fig. 1a). Negative Bouguer gravity anomaly ( -40 to $-20 \mathrm{mgal}$ ) substantiates granites in the region (Fig. 1b; Sandwell et al. 2014). However, the structure and tectonic regime under which the granite emplaced remain indeterminate. The sporadic granite pluton under present study emplaces within Champaner metasediments comprising intercalated sequence of quartzites and phyllites (Narukot Formation) exposed in the eastern portion of the dome. This is followed by polymict conglomerate with lithicwacke (Jaban Formation) and Mn-bearing phyllites and quartzites (Shivrajpur Formation) in the central part, whereas thin phyllite-quartzite bands with dolomitic limestone (Rajgarh Formation) characterize the western extension (Fig. 1c; Table 1; Gupta et al. 1992, 1997). These sequences are regionally metamorphosed up to greenschist facies (Jambusaria and Merh 1967) and preserve relic primary sedimentary structures (Srikarni and Das 1996). Further, isolated development of hornfelses and skarn zones are observed close to the granitic body (Das et al. 2009). The extreme WNW portion of the Narukot profile under present study exposes Mesozoic sedimentaries and the Deccan basalts.

The deformation pattern of southern Aravalli domain comprising Lunawada and Champaner Group are not comparable to the main Aravalli domain. The main Aravalli domain shows two deformation phases $\left(\mathrm{AD}_{1}\right.$ and $\left.\mathrm{AD}_{2}\right) . \mathrm{AD}_{1}$ exhibits $\mathrm{W}$ trending rootless reclined, inclined, and rarely upright isoclinal folds. On the other hand, $\mathrm{AD}_{2}$ are coaxial isoclinal folds with widely dispersed axial planes (Naha et al. 1966, 1969). Further south, the Lunawada Group displays $\mathrm{AD}_{3}$ deformation comprising $\mathrm{LF}_{1}$ and $\mathrm{LF}_{2}$ coaxial folds (L: Lunawada) with NE-trending axial planes. $\mathrm{LF}_{3}$ folds are open with 
Fig. 1 a Regional geological map showing extension of Aravalli Supergroup in Gujarat (after Mamtani et al. 2001). NW-trending batholith (Godhra Granite) constitutes the most conspicuous feature that demarcates the Lunawada Group at ENE and the Champaner Group at WSW. b Regional Bouguer gravity map showing extension of Aravalli Supergroup in Gujarat (Sandwell et al. 2014). c Geological map of study area (modified after Gupta et al. 1997). Oval structure along the E margin represents the Narukot dome with $\mathrm{N} 95^{\circ}$ axial trace. Dotted line across the dome and further $\mathrm{W}$ shows location of stations (1-32) for microtremor measurements (a)

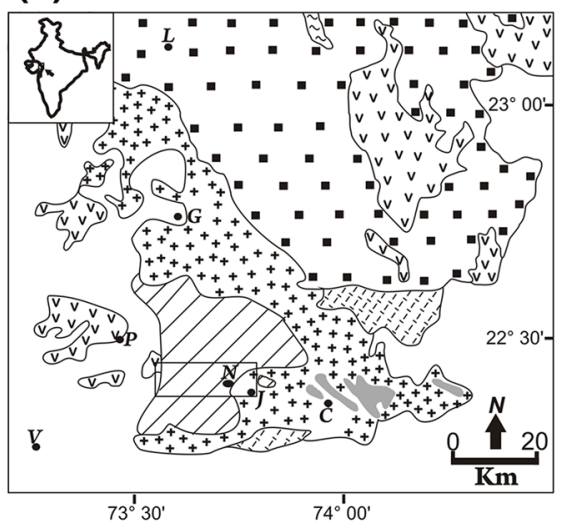

(b)

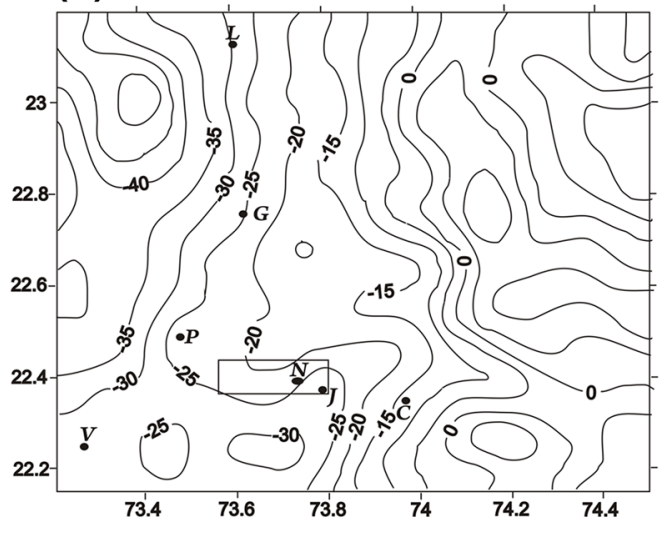

INDEX
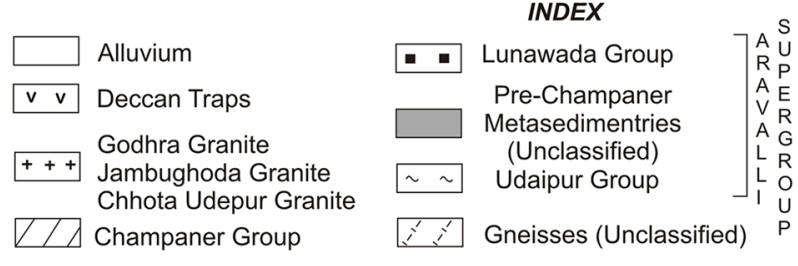

(25) Gravity Contrours (mgal)

$L=$ Lunawada $G=$ Godhra $P=$ Pavagadh $N=$ Narukot $N=$ Narukot
$J=$ Jambughoda $C=$ Chhota Udepur $V=$ Vadodara

(c)

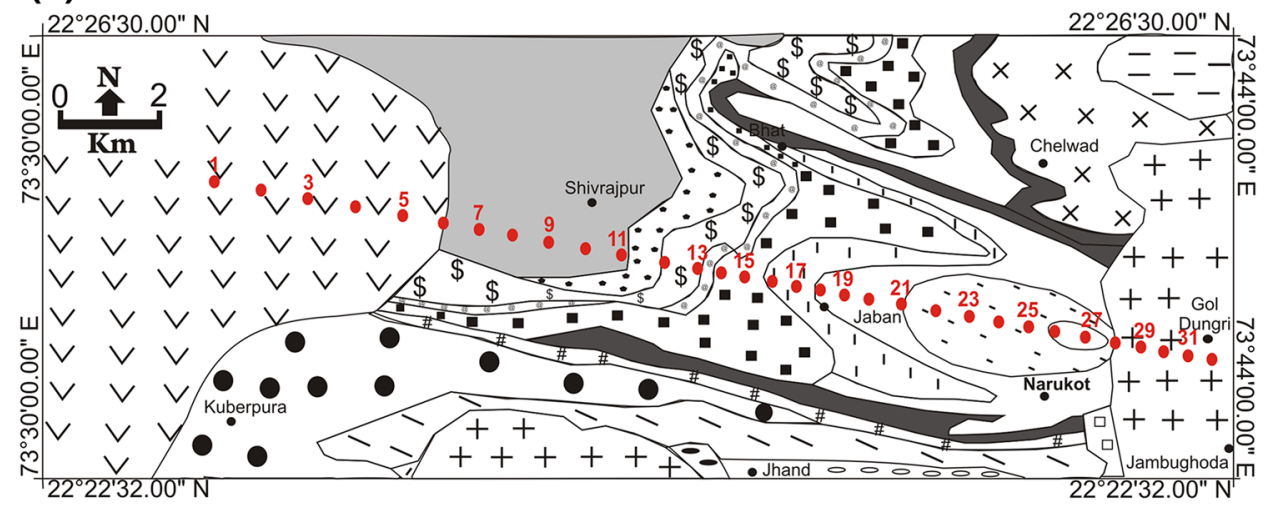
$22^{\circ} 22^{\prime} 32.00^{\prime \prime} \mathrm{N}$

\section{INDEX}
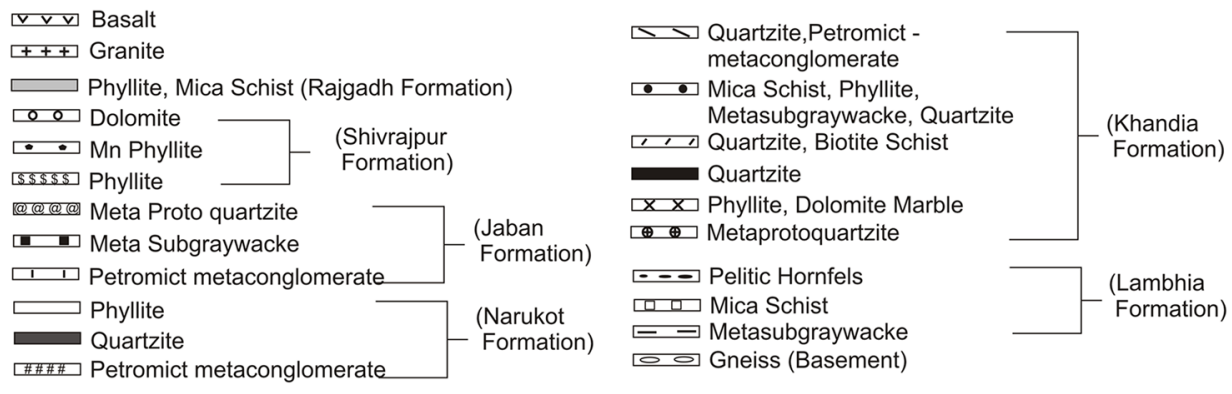

E- and NW-trending axial planes (Mamtani et al. 2001). Additionally, the Champaner Group demonstrates $\mathrm{AD}_{4}$ deformation developing upright folds with E-trending axial traces $\left(\mathrm{CF}_{1}\right)$ followed by open upright cross folds with $\mathrm{N}-\mathrm{S}$ axial traces $\left(\mathrm{CF}_{2}\right)$ emerging as large domal structures in Narukot and Poyali areas (Jambusaria and Merh 1967; Gopinath et al. 1977; Srikarni and Das 1996; Gupta et al. 1997; Karanth and Das 2000).
The domal character at Narukot is well preserved by quartzites that skirt the dome (Fig. 2a, b). Quartzite rimming N, E and S portion of dome shows discordant relation, steep dip, steep/vertical foliation and strong annealing. On the other hand, quartzites and phyllites in core region and towards the western margin show concordant relations, gentle westerly dip and regional metamorphism. Phyllites exposed adjacent to Narukot dome preserve S-C 
Table 1 Lithostratigraphy of southern Aravalli, Gujarat, W India after Gupta et al. (1992)

\begin{tabular}{|c|c|c|}
\hline Supergroup & Group & Formation \\
\hline $\begin{array}{l}\text { Post Delhi } \\
\text { Igneous } \\
\text { Intrusive }\end{array}$ & $\begin{array}{l}\text { Idar Granite } \\
\quad \text { (Malani Igneous suite) } \\
\text { Erinpura Granite } \\
\text { Godhra Granite } \\
\text { Sendra-Ambaji Granite }\end{array}$ & \\
\hline Delhi & $\begin{array}{l}\text { Sirohi } \\
\text { Kumbhalgarh } \\
\text { Gogunda } \\
\text { Phulad Ophiolites }\end{array}$ & \\
\hline Aravalli & Champaner & $\begin{array}{l}\text { Rajgarh } \\
\text { Shivrajpur } \\
\text { Jaban } \\
\text { Narukot } \\
\text { Khandia } \\
\text { Lambia }\end{array}$ \\
\hline & Lunawada & $\begin{array}{l}\text { Kadana } \\
\text { Bhukia } \\
\text { Chandanwara } \\
\text { Bhawanpura } \\
\text { Wagidora } \\
\text { Kalinjara }\end{array}$ \\
\hline
\end{tabular}

fabric (Passchier and Trouw 2005; Mukherjee 2011a, 2012, 2013a, b, 2014, 2015; Mukherjee and Kovi 2010a,b). Fieldwork did not reveal any visual effect of shear heating (Mukherjee and Mulchrone 2013; Mulchrone and Mukherjee 2015,2016 ) The $S$ - and C-planes meet at $\sim 24^{\circ}$. The dip direction of both $\mathrm{S}-\mathrm{C}$ fabrics is parallel to the plunge of open folds that characterizes western portion of the Narukot dome (Fig. 2c-e). Stereonet of lower hemisphere equal area projection containing $n=67$ foliations have been plotted. Beta intersection diagram represents superimposition of $\mathrm{N}-\mathrm{S}$ axial plane over the $\mathrm{E}-\mathrm{W}$ trends. Beta-1 and Beta-2 are respective fold axes of $\mathrm{CF}_{1}$ and $\mathrm{CF}_{2}$ producing dome and basin geometry (Fig. 2f).

\section{Microtremor studies}

Studies reveal that microtremors are activated by ambient noise that encapsulates the fundamental resonant frequency of near surface sediment horizons (Ohta et al. 1978; Celebi et al. 1987; Lermo et al. 1988; Nakamura 1989; Field et al. 1990; Hough et al. 1991; Yamanaka et al. 1994; Konno and Ohmachi 1998; Ibs-Vonseht and Wohlenberg 1999; Delgado et al. 2000a, b; Aki and Richards 2002). These resonating frequencies derived from microtremors strongly correlate with the velocity of seismic wave as well as the sediment thickness (Ibs-Vonseht and Wohlenberg 1999; Parolai et al.
2002). To characterize amplification of seismic wave for a given site, Nogoshi and Igarashi (1971) proposed a technique to normalize the source effect by taking the ratio of the horizontal (NS + EW component) and vertical component $(H / V)$ of the noise spectrum. Nakamura (1989) further popularized the method and its applications. The merits and demerits of this method are discussed by several workers and has been used extensively as a low cost tool for site characterization in estimating the resonant frequency and thickness of sedimentary layers, viz. Field and Jacob (1993), Parolai and Galiana-Merino (2006), Bonnefoy-Claudet et al. (2006), Garcia-Jerez et al. (2006), Zhao et al. (2007), Nakamura (2008), Bard (2008), Pilz et al. (2009), Lunedei and Albarello (2010), and Sánchez-Sesma et al. (2011).

We deployed a Lennartz seismometer ( $5 \mathrm{~s}$ period) and a City Shark-II data acquisition system to acquire ambient noise in forms of three components, viz. NS, EW, and vertical directions. The recording was carried out for $40 \mathrm{~min}$ at the rate of 100 samples/s per site (Sukumaran et al. 2011, fig. 3). All the 32 geophysical stations (Fig. 1c) arrayed for measurement run almost parallel to the axial trace $\left(\mathrm{N} 95^{\circ}\right)$ of the Narukot Dome (Fig. 1c). The station interval was decided considering topography along the profile line. The region with rolling topography from station 1-13 (Fig. 1c) was surveyed at $1 \mathrm{~km}$ interval, whereas the rugged terrain, stations 13-32 (Fig. 1c), was surveyed at $500 \mathrm{~m}$ interval.

The ratio between the Fourier amplitude spectra of the horizontal to the vertical (H/V) components of persisting Rayleigh waves were calculated from the ambient noise vibrations acquired from 32 stations using the GEOPSY (SESAME European Project 2004). The H/V spectral ratios were plotted between 0.2 and $25 \mathrm{~Hz}$ encompassing the complete range of resonating frequencies recorded within the study area (Fig. 3). These $\mathrm{H} / \mathrm{V}$ ratios were further processed individually to identify statistically significant spectral peaks using custom-written Matlab code. The statistically significant peaks were taken to be those peaks that were at least one standard deviation greater than the baseline activity. These peaks then correspond to significant fundamental resonating frequencies for each station. The significant fundamental resonating frequencies $f_{0}, f_{1}$ and $f_{2}$ were singled out for individual stations quantifying their amplitudes (Fig. 3; Table 2). Figure 3 illustrates a series of $\mathrm{H} / \mathrm{V}$ spectral frequency plots recorded from the study area. Station 22, 30 and 31 show the peaks at fundamental frequency $\left(f_{0}\right)$. Station 2 , 3 and 4 show dual frequency $\left(f_{0}\right.$, and $\left.f_{1}\right)$ with representing the boundary at both deeper and shallower levels. Station 15 and 29 too display dual frequency $\left(f_{0}\right.$, and $\left.f_{1}\right)$ but at different frequencies that correspond to the boundary at moderate to shallower depth level. However, station 32 
Fig. 2 a Structural map of the study area (modified after Gupta et al. 1997). b Geo-eye image of Narukot Dome. N-S axial trace overlay over WNW-ESE trend; discontinuous lines: shear in the region; $\mathrm{P} 1, \mathrm{P} 2$ and $\mathrm{P} 3$ : locations for field photographs. c-e Top-to-E ductile shear along vertical section. $S$ schistosity fabric dipping steeper than the C-plane. f Foliation surfaces as great circles $\left(n=67, \mathrm{~S}_{0}, \mathrm{~S}_{1}\right)$. g Beta intersection diagram representing superimposition of $\mathrm{N}-\mathrm{S}$ axial plane over E-W (2211 intersections of 67 planes). Beta 1 and Beta 2 are the respective fold axes of $\mathrm{CF}_{1}$ and $\mathrm{CF}_{2}$ producing dome and basin geometry. $\mathbf{h}$ Pie diagram $\left(n=67, \mathrm{~S}_{0}\right.$ and $\mathrm{S}_{1}$ ) showing similar fold axes of $\mathrm{CF}_{1}$ (i.e., $\mathrm{N} 275^{\circ}$ ). i Contoured pie diagram; $2,4,8$ and $16 \%$ contours per $1 \%$ area (a)

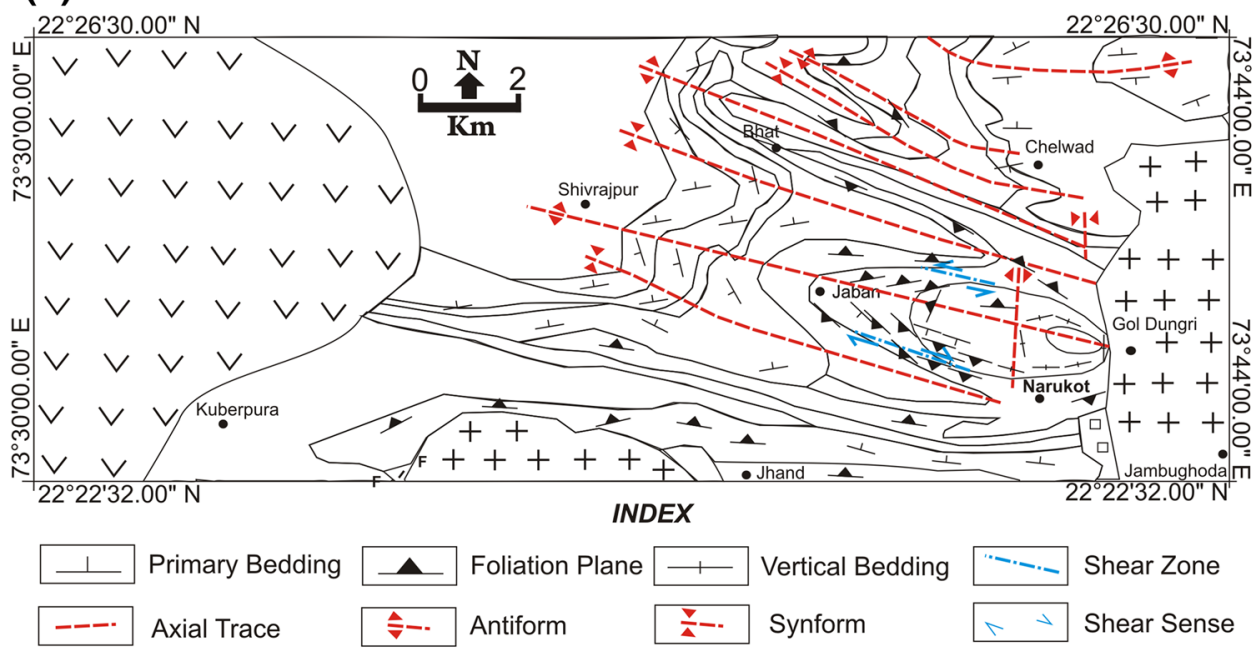

(b)

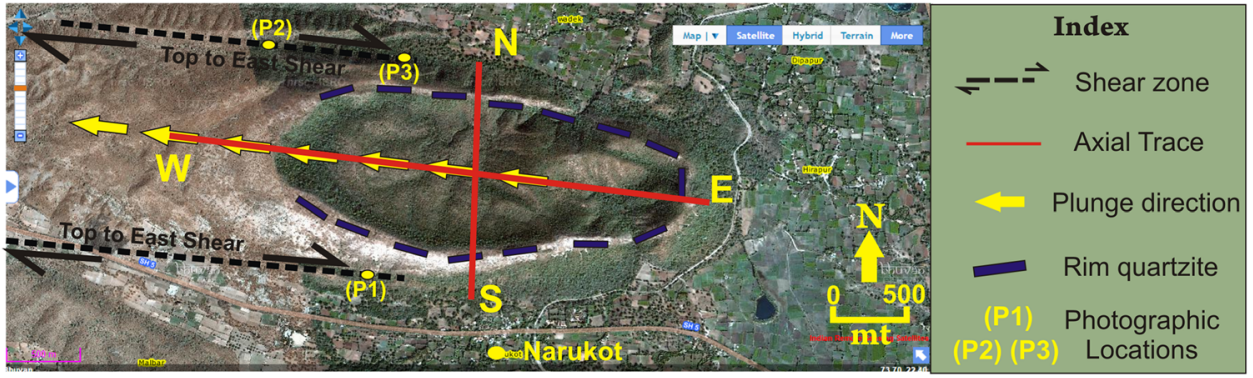

(c)

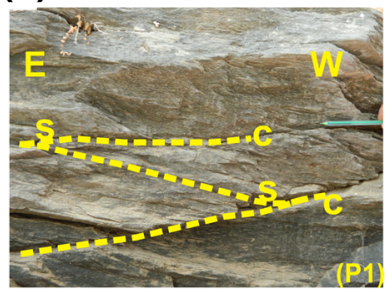

(d)

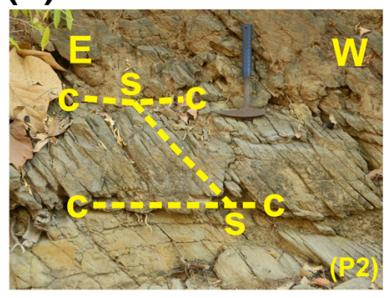

(e)
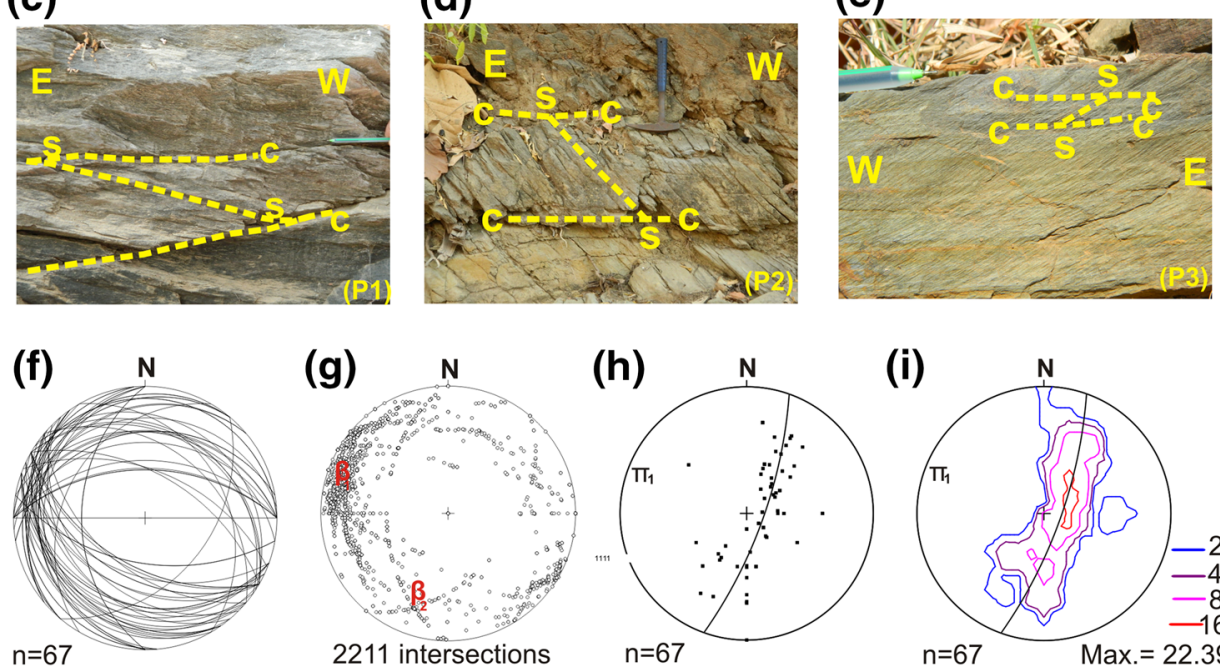
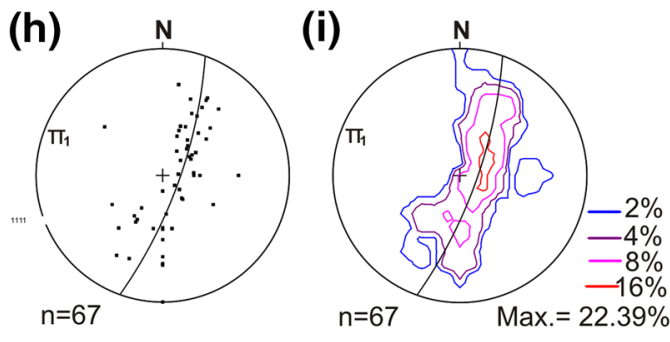

represent three frequencies $\left(f_{0}, f_{1}, f_{2}\right)$ incorporating three boundaries at shallow, moderate and deeper levels.

The thickness $(h)$ of soil/sediment layer over the bedrock can be related theoretically with the fundamental resonant frequency $\left(f_{\mathrm{r}}\right)$ of $\mathrm{H} / \mathrm{V}$ spectral ratio (Ibs-Vonseht and Wohlenberg 1999)

$h=a f_{r}^{b}$, where $a$ and $b$ are obtained by nonlinear regression between the thickness and the fundamental resonant frequency. For a given fundamental resonant frequency, if the velocity of seismic waves $\left(V_{\mathrm{s}}\right)$ for a given interphase is known, the depth of the interphases is given by Parolai et al. (2002):

$h=\frac{V_{\mathrm{s}}}{4 f_{\mathrm{r}}}$. 

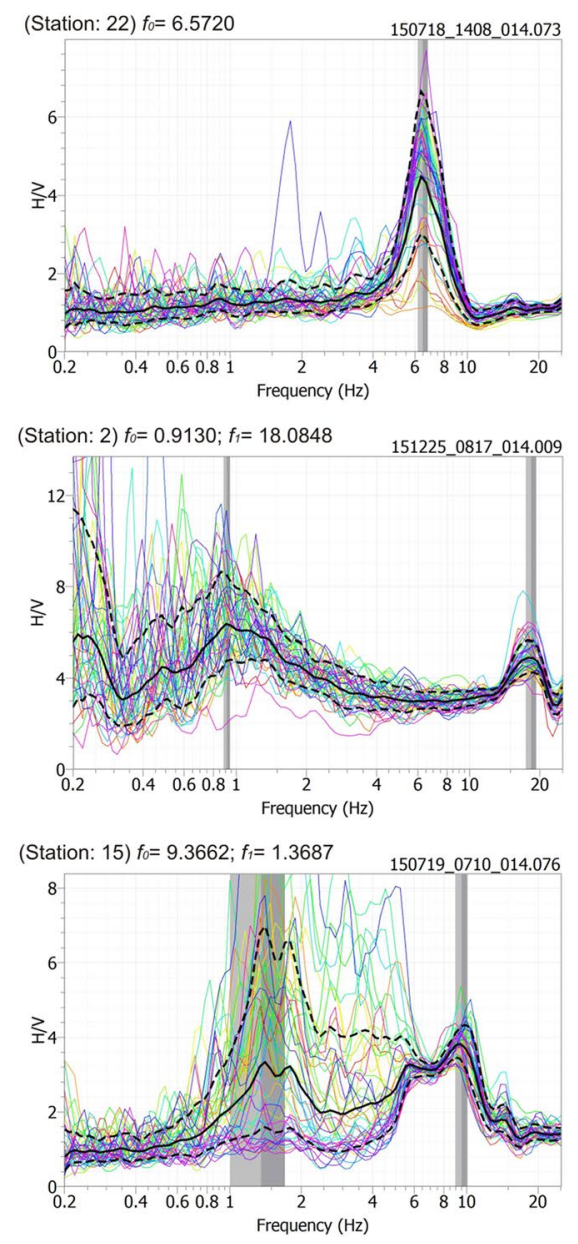
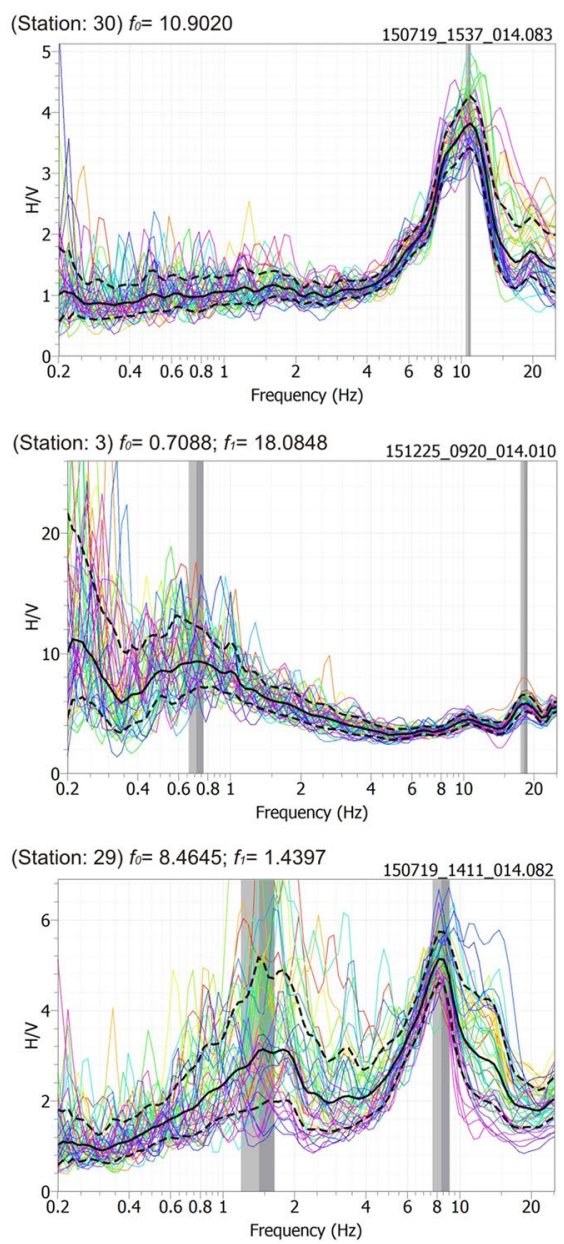
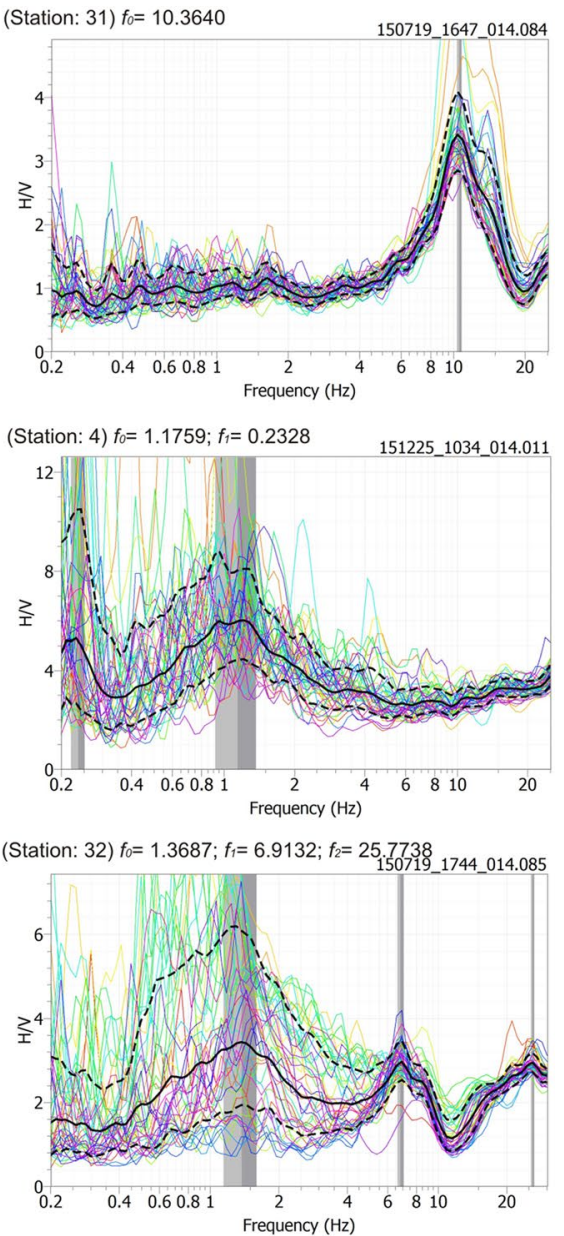

Fig. $3 \mathrm{H} / \mathrm{V}$ spectral frequency plot recorded for the representative stations from the study area. Station 22, 30 and 31 show the peaks at fundamental frequency $\left(f_{0}\right)$; station 2,3 and 4 show dual frequency $\left(f_{0}\right.$, and $\left.f_{1}\right)$ with representing the interphases at both deeper and shallower levels; station 15 and 29 also show dual frequency $\left(f_{0}\right.$, and $\left.f_{1}\right)$

On the other hand, if the depth of the interphase in known based on available core record, the velocity of seismic waves $\left(V_{\mathrm{s}}\right)$ can be determined using Eq. (2).

In the present study, we used a record of a private borehole $300 \mathrm{ft}(91.4 \mathrm{~m})$ closer to station 29, in Hirapur Village, east of Narukot dome. The records suggest 7-ft (2.13$\mathrm{m})$ thick soil unit, followed by $15-\mathrm{ft}(4.57-\mathrm{m})$ thick white fine-grained sand (alteration product of in situ granite); and $278 \mathrm{ft}(84.7 \mathrm{~m})$ of massive granite. In the present case, we categorized both the soil unit and altered granite unit under the regolith. Using the observed depth of regolith-granite boundary $(6.70 \mathrm{~m})$, we computed $V_{\mathrm{s}}(227 \mathrm{~m} / \mathrm{s})$ for the regolith unit at station 29 using Eq. (2). The depth of regolithgranite boundary for stations $28,30,31$ and 32 has been estimated using the above computed value of $V_{\mathrm{s}}$. In addition, substituting the value of $V_{\mathrm{s}}$ in Eq. 2,

$h=(56.8) f_{\mathrm{r}}^{-1}$. but at different frequencies that correspond to the interphases at moderate to shallower depth level. However, station 32 represent three frequencies $\left(f_{0}, f_{1}, f_{2}\right)$ incorporating three interphases at shallow, moderate and deeper levels

Equation (3) derived from the study area is comparable to the equation derived for a granitic terrain around Bangalore (state Karnataka, India) decoding interphase of soilregolith from that of granites (Dinesh et al. 2010), viz.

$h=(58.3 \pm 8.8) f_{\mathrm{r}}^{-0.95 \pm 0.1}$.

In this context, we preferred the equation established by Dinesh et al. (2010) in this study to derive theoretical depths of interphases as they had established the relationship using a larger number of observed borehole logs.

Further, grouping fundamental resonating frequency, geology and structural data from the study area, we identify two distinct rheological boundaries, viz. $0.2219-10.364 \mathrm{~Hz}$ that is inferred to record boundary between Champaner metasediment and granites (C-Gr boundary) and 10.902$27.1119 \mathrm{~Hz}$ that differentiates phyllites from quartzites $(\mathrm{P}-$ Qr boundary) (Figs. 4, 5). The other boundaries identified along the $\mathrm{W}$ margin of the profile, viz. $0.7088-12.6896 \mathrm{~Hz}$ 
Table 2 Fundamental resonant frequency $f_{0}, f_{1}$ and $f_{2}$ for station 1-32 across Narukot Dome and in its western extension along a WNW profile

\begin{tabular}{|c|c|c|c|c|c|c|c|c|c|}
\hline Stations & $f_{\mathrm{o}}$ & $\begin{array}{l}\text { Depth in } m \\
\text { (Eq. 3) }\end{array}$ & $\begin{array}{l}\text { Depth in } \mathrm{m} \\
\text { (Eq. } 4 \text { ) }\end{array}$ & $f_{1}$ & $\begin{array}{l}\text { Depth in } \mathrm{m} \\
\text { (Eq. 3) }\end{array}$ & $\begin{array}{l}\text { Depth in } \mathrm{m} \\
\text { (Eq. 4) }\end{array}$ & $f_{2}$ & $\begin{array}{l}\text { Depth in } \mathrm{m} \\
\text { (Eq. 3) }\end{array}$ & $\begin{array}{l}\text { Depth in } \mathrm{m} \\
\text { (Eq. 4) }\end{array}$ \\
\hline 1 & 0.2328 & 243.814 & 232.828 & 0.913 & 62.169 & 63.565 & & & \\
\hline 2 & 0.913 & 62.169 & 63.565 & 18.0848 & 3.139 & 3.726 & & & \\
\hline 3 & 0.7088 & 80.079 & 80.848 & 18.0848 & 3.139 & 3.726 & & & \\
\hline 4 & 1.1759 & 48.269 & 49.982 & 0.2328 & 243.814 & 232.828 & & & \\
\hline 5 & 0.2328 & 243.814 & 232.828 & & & & & & \\
\hline 7 & 12.6896 & 4.473 & 5.217 & 1.3011 & 43.625 & 45.402 & & & \\
\hline 8 & 1.3011 & 43.625 & 45.402 & 25.7738 & 2.202 & 2.661 & & & \\
\hline 9 & 1.18284 & 47.986 & 49.704 & 12.3244 & 4.605 & 5.363 & & & \\
\hline 10 & 0.7456 & 76.127 & 77.053 & 25.7738 & 2.202 & 2.661 & & & \\
\hline 11 & 27.1119 & 2.094 & 2.536 & 1.1759 & 48.269 & 49.982 & & & \\
\hline 12 & 12.6896 & 4.473 & 5.217 & & & & & & \\
\hline 13 & 18.0848 & 3.139 & 3.726 & & & & & & \\
\hline 14 & 10.902 & 5.206 & 6.026 & & & & & & \\
\hline 15 & 9.3662 & 6.060 & 6.961 & 1.3687 & 41.470 & 43.269 & & & \\
\hline 16 & 8.904 & 6.375 & 7.304 & 18.0848 & 3.139 & 3.726 & 1.2369 & 45.889 & 47.638 \\
\hline 17 & 14.7704 & 3.843 & 4.516 & & & & & & \\
\hline 18 & 1.8543 & 30.610 & 32.426 & 25.7738 & 2.202 & 2.661 & 4.3838 & 12.948 & 14.319 \\
\hline 19 & 1.5145 & 37.478 & 39.302 & 20.0113 & 2.836 & 3.384 & & & \\
\hline 20 & 10.364 & 5.477 & 6.323 & 1.6758 & 33.870 & 35.699 & & & \\
\hline 21 & 27.1119 & 2.094 & 2.536 & 19.0237 & 2.984 & 3.551 & & & \\
\hline 22 & 6.572 & 8.637 & 9.747 & & & & & & \\
\hline 23 & 1.8543 & 30.610 & 32.426 & & & & & & \\
\hline 24 & 1.4397 & 39.425 & 41.239 & & & & & & \\
\hline 25 & 18.0848 & 3.139 & 3.726 & & & & & & \\
\hline 26 & 18.0848 & 3.139 & 3.726 & & & & & & \\
\hline 27 & 19.0237 & 2.984 & 3.551 & & & & & & \\
\hline 28 & 5.3676 & 10.575 & 11.813 & & & & & & \\
\hline 29 & 8.4645 & 6.706 & 7.664 & 1.4397 & 39.425 & 41.239 & & & \\
\hline 30 & 10.902 & 5.206 & 6.026 & & & & & & \\
\hline 31 & 10.364 & 5.477 & 6.323 & & & & & & \\
\hline 32 & 1.3687 & 41.470 & 43.269 & 6.9132 & 8.210 & 9.289 & 25.7738 & 2.202 & 2.661 \\
\hline
\end{tabular}

The depths of rheological boundaries are calculated using Eq. 3 ( $h=56.8 f_{\mathrm{r}}^{-1}$ : derived from borehole data from station 29 whereas Eq. 4 $\left(h=58.3 \pm 8.8 f_{r}^{-0.95 \pm 0.1}\right.$; Dinesh et al. 2010)

frequencies distinguish the boundary between the Champaner metasediments and the Mesozoic sediments. On the other hand, at stations 2 and 3, $18.0848 \mathrm{~Hz}$ frequency distinguishes thin Deccan traps from Mesozoic sediments.

\section{Champaner-granite boundary}

The Champaner-granite boundary ( $\mathrm{C}-\mathrm{Gr}$ boundary) occurs at a shallower depth towards $\mathrm{E}$ than at the $\mathrm{W}$ margin of the profile showing an arched-up geometry (Fig. 5). The granite pluton attains shallowest depth calculated from surface underneath station $20(35.69 \mathrm{~m})$ and station $23(32.42 \mathrm{~m})$ followed by a significant depth, or a 'low', beneath station $6(243.64 \mathrm{~m})$ and station $1(232.82 \mathrm{~m})$ towards W. C-Gr boundary follows a steep slope between stations $7(45.40 \mathrm{~m})$ and $6(243.64 \mathrm{~m})$. The low along profile between stations 1 and 6 marks an extension of the younger Champaner rocks exposed around stations 7 and 8 (Rajgarh Formation) and is confirmed based on aeromagnetic data (Sahu 2012).

\section{Phyllite-quartzite boundary}

The phyllite-quartzite ( $\mathrm{P}-\mathrm{Qr}$ boundary) sequence of Champaner Group is well exposed in the western 
Fig. 4 Fundamental resonant frequency of 1-32 stations along WNW trending profile. The diameter of bubbles captures amplitude of fundamental resonant frequency. The blue color represent frequency for $\mathrm{C}-\mathrm{Gr}$ boundary $\left(\mathrm{L}_{1}\right)$ that ranges between 0.2219 and $10.364 \mathrm{~Hz}$, whereas red color represents frequency for P-Qr boundary $\left(\mathrm{L}_{2}\right)$ that ranges between 10.902 and $27.1119 \mathrm{~Hz}$

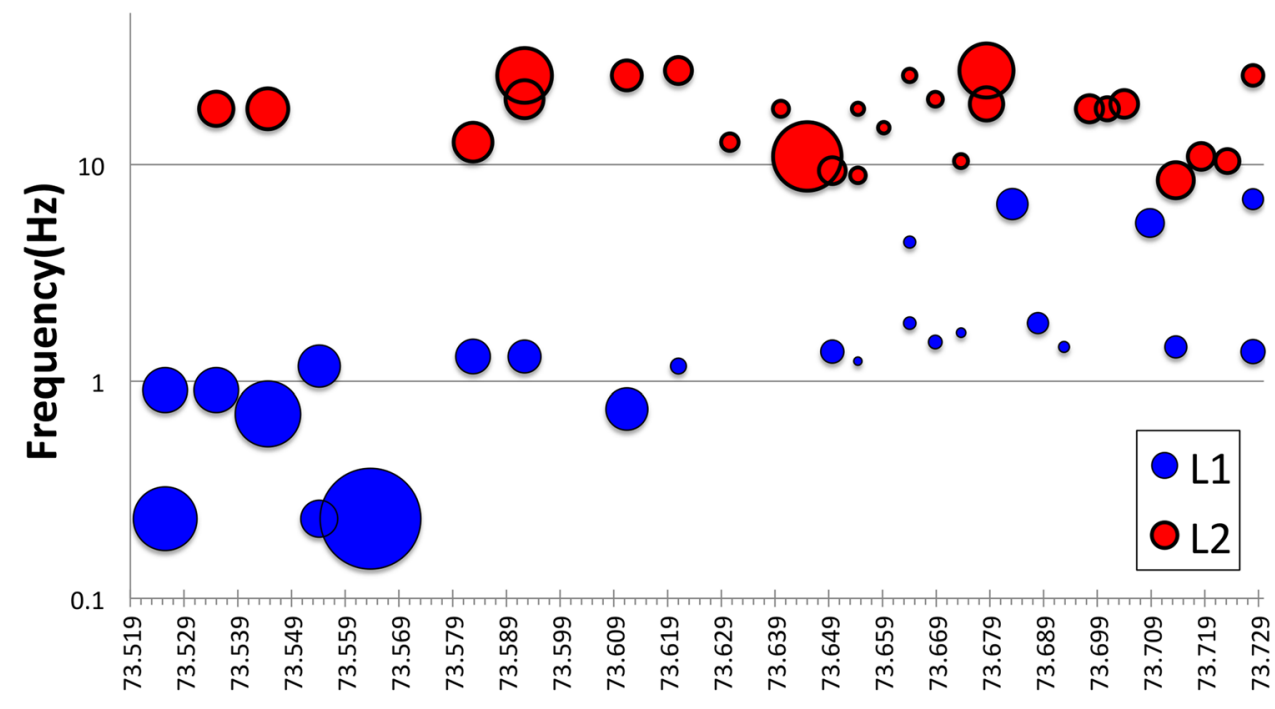

Longitude(Degree)

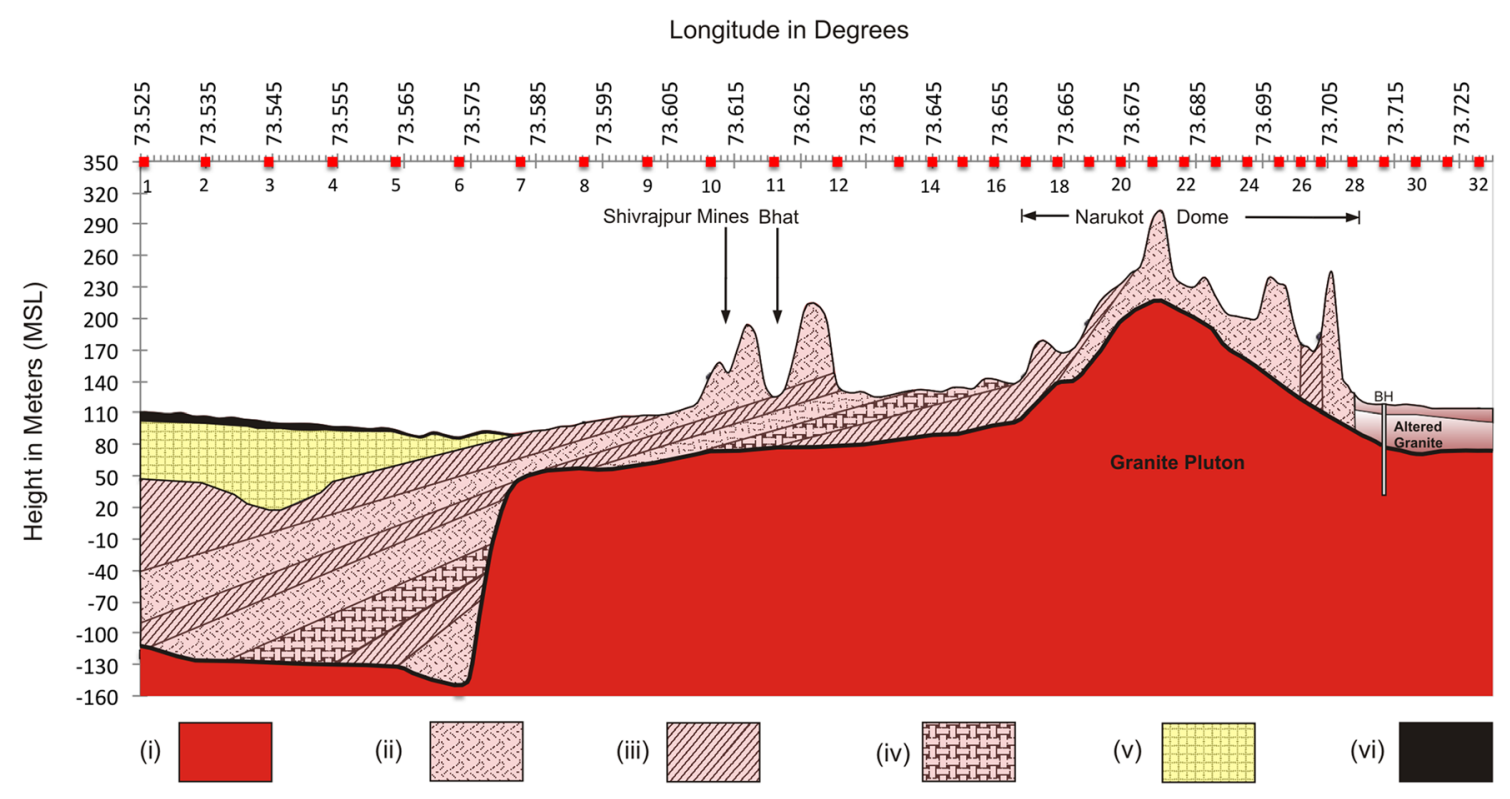

Fig. 5 Layered model for the profile along Narukot dome and to its W. Subsurface interphases of C-Gr and P-Qr plotted with reference to the surface elevation. C-Gr boundary shows the granite pluton hump (from station 16 to 29) towards eastern part of the profile. The $\mathrm{C}-\mathrm{Gr}$ interphase in $\mathrm{W}$ distinguishes a steep wall of the pluton (between stations 6 and 7) taking pluton further deeper to $243.64 \mathrm{~m}$ (station 6) and $232.82 \mathrm{~m}$ (station 1). The P-Qr boundary shows

extension of Narukot dome. During the field studies, boundary of different lithology and their trends were recorded and mapped (Figs. 1, 2). Lithology and structural trends were plotted along the topographic profile, extrapolating their contact up to the C-Gr boundary (Fig. 5). a steep plunge $\mathrm{E}$ of the granite pluton hump and $15^{\circ}$ gentle plunge due W. The profile highlights subsurface extension of the Champaner Group further W overlain by Mesozoic sedimentaries and thin cover of Deccan basalt between stations 1 and 7. Numbers in the figure indicate (i) granite, (ii) quartzites, (iii) phyllites, (iv) conglomerate, (v) Mesozoic sedimentaries, and (vi) Deccan basalt

\section{Other rheological boundaries}

In the western portion of the profile, the $\mathrm{C}-\mathrm{Gr}$ boundary is $\sim 240 \mathrm{~m}$ deep. The Rajgarh Formation in this part directly overlies granites deduced from aeromagnetic 
data (Sahu 2012). The boundary between the Rajgarh Formation and Mesozoic sediments is $\sim 70 \mathrm{~m}$ deep. The boundary between the Mesozoic sediments and Deccan basalt is $\sim 1-2 \mathrm{~m}$ deep (Fig. 5).

\section{Discussions}

The microtremor study reveals Champaner-granite boundary as the most conspicuous rheological boundary that emphasizes the morphology of subsurface granite pluton (Fig. 5). The granitic pluton forms a hump between stations 29 and 16 followed by gentle westerly dip up to station 7 . The profile between stations 6 and 7 highlights a steep wall of the granite pluton, with 230-m deep C-Gr boundary, thereafter follows a rolling topography till station 1 . On the other hand, the Champaner metasediment terminates abruptly above granite plutons imparting a discordant relation. The sporadic granitic plutons emplaced in the terrain presumably uprooted the Champaner metasediments giving "rootless" characteristic especially at Narukot dome and to its West (Fig. 5). Further northeast of the Narukot dome, at Gol Dungari such rootless character can be deciphered (Limaye and Joshi 2016). The estimated vertical thickness of Champaner metasediments varies as: $30 \mathrm{~m}$ (station 20), $100 \mathrm{~m}$ (station 21) and goes to a maximum of $136 \mathrm{~m}$ (station 12) at the Shivrajpur Manganese Mine. In the W extension of Narukot dome, the estimated thickness of Rajgarh Formation is $\sim 108 \mathrm{~m}$ followed by $70-\mathrm{m}$ thick Mesozoic sediment capped by 1-1.5-m thick Deccan basalt.

To present the relation between the pluton and associated deformation, we draw a geological cross-section across Narukot Dome and its extension towards W, by applying standard method adopted in geological studies, extrapolating surface geology and structural trends up to regolith-granite rheological boundaries delineated by microtremor studies (Figs. 2, 5). The sporadic emplacement of plutonic bodies produced asymmetric plunge along the dome. The Champaner metasediments between stations 23 and 29, E of the pluton hump, are tightly folded and plunge steeply towards E (Fig. 2), whereas to the $\mathrm{W}$ of pluton hump (station 20) metasediments show open folds and plunge $15^{\circ}$ due $\mathrm{W}$ (Fig. 2). However, the fold axis of both tight (towards E) and open folds (towards W) across the Narukot dome trends $\mathrm{N}^{\circ} 5^{\circ}$ signifying the same deformation phase (Fig. 2). The accompanied deformation in form of open folds with $\mathrm{N}$ and NW trends has further resulted into dome and basin geometry. A more detail mechanism of doming (such as Mukherjee 2011b; Mukherjee et al. 2010; Mukherjee and Mulchrone 2012) remains a subject of future research. Finally, pluton morphology, selective metamorphism and related deformations favor syntectonic granite emplacement. Similar observations have been made in the Lunawada region—further NE of the study area (Mamtani et al. 2001).

\section{Conclusions}

(a) Microtremor method is a handy tool for geoscientists to infer morphology of subsurface plutons underneath meta-sedimentary sequence.

(b) Microtremor method would update the results along with field records to estimate thickness and to further project subsurface attitudes of the country rock.

(c) Country rock and pluton boundary, contact metamorphism and associated deformation connote syntectonic pluton emplacement.

Acknowledgements AUJ was supported by DST PURSE fellowship. AUJ, DAS, MAL, MJC, MNB and SPM thank Prof. L.S. Chamyal (Head, Department of Geology, MS University Baroda) for support and encouragement. IAP thanks Head, CSIR Fourth Paradigm Institute, for support. GR was supported by JC Bose National Fellowship and UGC Centre for Advanced Study. SM was funded by IIT Bombay's CPDA grant. Discussion with M. Mamtani (IIT Kharagpur) and JL Vigneresse (University of Lorraine) is acknowledged. We further acknowledge numerous constructive suggestions from both anonymous reviewer and Lucie Nováková. Thanks to the anonymous Handling Editor, Chief Editor: Christian Dullo and the Managing Editor: Monika Dullo. SM thanks IIT Bombay for providing him a research sabbatical for the year 2017 .

\section{References}

Aki KP, Richards G (2002) Quantitative seismology, 2nd edn. University Science Book, Sausalito, pp 1-687

Bard PY (2008) The H/V technique: capabilities and limitations based on the results of the SESAME project. Bull Earthq Eng 6:1-2

Benn K, Odonne F, de Saint Blanquat M (1998) Pluton emplacement during transpression in brittle crust: new views from analogue experiments. Geology 26:1079-1082

Bonnefoy-Claudet S, Cornou C, Bard PY et al (2006) H/V ratio: a tool for site effects evaluation. Results from 1-D noise simulations. Geophys J Int 167:827-837

Bott MHP (1955) A Geophysical study of the Granite problem. Q J Geol Soc Lond 112:45-67

Celebi M, Dietel C, Prince J et al (1987) Site amplification in Mexico City (determined from 19 September 1985 strong-motion records and from recording of weak motions). In: Cakmak AS (ed) Ground motion and engineering seismology. Elsevier, Amsterdam, pp 141-152

Crawford AR (1975) $\mathrm{Rb}-\mathrm{Sr}$ age determination for the Mount Abu granite and related rocks of Gujarat. J Geol Soc India 16:20-28

Cruden AR (2008) Emplacement mechanisms and structural influences of a younger granite intrusion into older wall rocks-a principal study with application to the Götemar and Uthammar granites. Site-descriptive modeling SDM-Site Laxemar, SKB Report R-08-138:1-45

Das S, Singh PK, Sikarni C (2009) A preliminary study of thermal metamorphism in the Champaner Group of rocks in Panchmahals and Vadodara districts of Gujarat. Indian J Geosci 63:373-382

Delgado J, Lopez C, Estevez A, Cuenca A, Molina S, (2000a) Microtremors as a geophysical exploration tool: applications and limitations. Pure Appl Geophys 157:1445-1462

Delgado J, López Casado C, Estévez A, Giner J, Cuenca A, Molina S (2000b) Mapping soft soils in the Segura river valley (SE Spain): 
a case study of microtremors as an exploration tool. J Appl Geophys 45:19-32

Dinesh BV, Nair GJ, Prasad AGV et al (2010) Estimation of sedimentary layer shear wave velocity using micro-tremor $h / v$ ratio measurements for Bangalore city. Soil Dyn Earthq Eng 30:1377-1382

Dixit MM, Tewari HC, Rao CV (2010) Two-dimensional velocity model of the crust beneath the South Cambay Basin, India from refraction and wide-angle reflection data. Geophys J Int 181:635-652

Field E, Jacob K (1993) The theoretical response of sedimentary layers to ambient seismic noise. Geophys Res Lett 20:2925-2928

Field EH, Hough SE, Jacob KH (1990) Using microtremors to assess potential earthquake site response: a case study in Flushing Meadows, New York City. Bull Seismol Soc Am 80:1456-1480

Garcia-Jerez A, Luzon F, Navarro M et al (2006) Characterization of the sedimentary cover of the Zafarraya basin, southern Spain, by means of ambient noise. Bull Seismol Soc Am 96:957-967

Gopalan K, Trivedi JR, Merh SS et al (1979) Rb-Sr age of Godhra and related granites, Gujarat. Proc Indian Acad Sci 88A:7-17

Gopinath K, Rao ADP, Agrawal GG et al (1977) Precambrians of Baroda and Panchmahals districts. Elucidation of Stratigraphy and Structure. Records Geol Surv India 73:1-52

Goyal N, Pant PC, Hansda PK, Pandey BK (2001) Geochemistry and $\mathrm{Rb}-\mathrm{Sr}$ age of the late Proterozoic Godhra Granite of Central Gujarat, India. J Geol Soc India 58:391-398

Guéguen P, Cornou C, Garambois S et al (2006) On the limitation of the $\mathrm{H} / \mathrm{V}$ spectral ratio using seismic noise as an exploration tool: application to the Grenoble Valley (France), a small apex ratio basin. Pure Appl Geophys 164:1-20

Gupta SN, Mathur RK, Arora YK (1992) Lithostratigraphy of Proterozoic rocks of Rajasthan and Gujarat-a review. Records Geol Surv India 115:63-85

Gupta SN, Arora YK, Mathur RK et al (1997) The Precambrian Geology of the Aravalli region, Southern Rajasthan and NE Gujarat. Mem Geol Surv India 123:1-262

Hough SE, Field EH, Jacob KH (1991) Using microtremors to assess site-specific earthquake hazard. In: Proceedings of the international conference on seismic zonation, vol 4, pp 385-392

Ibs-Vonseht M, Wohlenberg J (1999) Microtremor measurements used to map thickness of soft sediments. Bull Seismol Soc Am $89: 250-259$

Jambusaria BB, Merh SS (1967) Deformed greywacke conglomerates of Jaban near Shivrajpur, Panchmahals district, Gujarat. Indian Miner 8:6-10

Kaila KL, Krishna VG, Mall DM (1981) Crustal structure along Mehamdabad-Billimora profile in the Cambay Basin, India from deep Seismic soundings. Tectonophysics 76:99-130

Kanai K (1957) The requisite conditions for the predominant vibration of ground. Bull Earthq Res Inst 35:457-471

Karanth RV, Das S (2000) Deformational history of the Pre-Champaner gneissic complex in Chhota Udepur area, Vadodara district, Gujarat. Indian J Geol 72:43-54

Konno K, Ohmachi T (1998) Ground-motion characteristics estimated from spectral ratio between Horizontal and Vertical components of microtremor. Bull Seismol Soc Am 88:228-241

Lermo J, Rodriguez M, Singh SK (1988) The Mexico earthquake of September 19, 1985. Natural period of sites in the valley of Mexico from microtremor measurements and strong motion data. Earthq Spectra 4:805-814

Limaye MA, Joshi AU (2016) Rootless folds over granites: An example from Lambia formation, Champaner Group. Abstract published in XXX Gujarat Science Congress organized by KSKV University Bhuj, Kutch, p 294
Lunedei E, Albarello D (2010) Theoretical HVSR curves from full wave field modeling of ambient vibrations in a weakly dissipative layered Earth. Geophys J Int 18:1093-1108

Mamtani MA, Greiling RO (2005) Granite emplacement and its relation with regional deformation in the Aravalli Mountain Belt (India) - inferences from magnetic fabric. J Struct Geol 27:2008-2029

Mamtani MA, Merh SS, Karanth RV et al (2001) Time relationship between metamorphism and deformation in Proterozoic rocks of the Lunawada region, southern Aravalli Mountain Belt (India) — a microstructural study. J Asian Earth Sci 19:195-205

McSween HY, Harvey RP Jr (1997) Concord plutonic suite: PreAcadian gabbro-syenite intrusions in the southern Appalachians. In: Sinha AK, Whalen JB, Hogan JB (eds) Geol Soc Am, vol 191, pp 221-234

Mukherjee S (2011a) Mineral fish: their morphological classification, usefulness as shear sense indicators and genesis. Int $\mathrm{J}$ Earth Sci 100:1303-1314

Mukherjee S (2011b) Estimating the Viscosity of Rock Bodies- a comparison between the Hormuz- and the Namakdan salt domes in the Persian Gulf, and the Tso Morari Gneiss Dome in the Himalaya. Indian J Geophys Union 15:161-170

Mukherjee S (2012) Simple shear is not so simple Kinematics and shear senses in Newtonian viscous simple shear zones. Geol Mag 149:819-826

Mukherjee S (2013a) Deformation microstructures in rocks. Springer, New York, pp 1-111

Mukherjee S (2013b) Higher Himalaya in the Bhagirathi section (NW Himalaya, India): its structures, backthrusts and extrusion mechanism by both channel flow and critical taper mechanisms. Int J Earth Sci 102:1851-1870

Mukherjee S (2014) Atlas of shear zone structures in meso-scale. Springer, New York, pp 1-124

Mukherjee S (2015) Atlas of structural geology. Elsevier, Amsterdam, pp 1-165

Mukherjee S, Koyi HA (2010a) Higher Himalayan Shear Zone, Sutlej section: structural geology and extrusion mechanism by various combinations of simple shear, pure shear and channel flow in shifting modes. Int J Earth Sci 99:1267-1303

Mukherjee S, Koyi HA (2010b) Higher Himalayan Shear Zone, Zanskar Indian Himalaya: microstructural studies and extrusion mechanism by a combination of simple shear and channel flow. Int J Earth Sci 99:1083-1110

Mukherjee S, Mulchrone KF (2012) Estimating the viscosity and Prandtl number of the Tso Morari crystalline gneiss dome, Indian western Himalaya. Int J Earth Sci 101:1929-1947

Mukherjee S, Mulchrone KF (2013) Viscous dissipation pattern in incompressible Newtonian simple shear zones: an analytical model. Int J Earth Sci 102:1165-1170

Mulchrone KF, Mukherjee S (2015) Shear senses and viscous dissipation of layered ductile simple shear zones. Pure Appl Geophys 172:2635-2642

Mulchrone KF, Mukherjee S (2016) Kinematics and shear heat pattern of ductile simple shear zones with 'slip boundary condition'. Int J Earth Sci 105:1015-1020

Mukherjee S, Talbot CJ, Koyi HA (2010) Viscosity estimates of salt in the Hormuz and Namakdan salt diapirs, Persian Gulf. Geol Mag 147:497-507

Naha K, Chaudhuri AK, Bhattacharyya AC (1966) Superposed folding in the older Precambrian rocks around Sangat, Central Rajasthan, India. Neues Jahrbuch für Geologie und Paläontologie Abh 126:205-230

Naha K, Venkatesubramanyam CS, Singh RP (1969) Upright folding of varying intensity on isoclinal folds of diverse orientation: 
a study from early Precambrian of western India. Geol Rund 58:929-950

Nakamura Y (1989) A method for dynamic characteristics estimation of subsurface using microtremor on the ground surface. Q Railw Tech Res Inst (Japan) 30:25-30

Nakamura Y (2008) On the H/V spectrum. In: The 14th world conference on earthquake engineering, Beijing, pp 1-10

Nogoshi M, Igarashi T (1971) On the amplitude characteristics of microtremor (part 2) (in Japanese with English abstract). J Seismol Soc Japan 24:26-40

Ohta Y, Kagami H, Goto N et al (1978) Observation of 1- to 5-second microtremors and their application to earthquake engineering. Part-I: comparison with long-period accelerations at the TokachiOki earthquake of 1968. Bull Seismol Soc Am 68:767-779

Parolai S, Galiana-Merino JJ (2006) Effect of transient seismic noise on estimates of $\mathrm{h} / \mathrm{v}$ spectral ratios. Bull Seismol Soc Am 96:228-236

Parolai S, Bormann P, Milkereit C (2002) New relationships between Vs, thickness of sediments, and resonance frequency calculated by the $\mathrm{H} / \mathrm{V}$ ratio of seismic noise for the Cologne Area (Germany). Bull Seismol Soc Am 92:2521-2527

Passchier CW, Trouw R (2005) Microtectonics, 2nd edn. Springer, New York, pp 1-366

Paudyal YR, Yatabe R, Bhandary NP et al (2013) Basement topography of the Kathmandu basin using microtremor observation. J Asian Earth Sci 62:627-637

Pilz M, Parolai S, Leyton F et al (2009) A comparison of site response techniques using earthquake data and ambient seismic noise analysis in the large urban areas of Santiago de Chile. Geophys J Int 178:713-728

Pitcher WS (1979) The nature, ascent and emplacement of granitic magmas. J Geol Soc Lond 136:627-662

Rao VV, Sain K, Reddy PR et al (2006) Crustal structure and tectonics of the northern part of the Southern Granulite Terrene, India. Earth Planet Sci Lett 251:90-103

Rošer J, Gosar A (2010) Determination of Vs 30 for seismic ground classification in the Ljubljana Area, Slovenia. Acta Geotech Slov 1:63-76

Sahu BK (2012) Aeromagnetic data analysis of the southern Aravalli Fold Belt: its implications in understanding the inter-relationship among the migmatites and gneissic rocks, Aravalli Supracrustals and Godhra Granite. J Geol Soc India 80:255-261

Sánchez-Sesma FJ, Rodríguez M, Iturrarán-Viveros U et al (2011) A theory for microtremor $\mathrm{H} / \mathrm{V}$ spectral ratio: application for a layered medium. Geophys J Int 186:221-225

Sandwell DT, Müller RD, Smith WHF, Garcia E, Francis R (2014) New global marine gravity model from CryoSat-2 and Jason-1 reveals buried tectonic structure. Science 346:65-67. http:// topex.ucsd.edu/cgi-bin/get_data.cgi
Sastry RS, Nagarajan N, Sarma SVS (2008) Electrical imaging of deep crustal features of Kutch, India. Geophys J Int 172:934-944

SESAME European Project EVG1-CT-2000-00026 (2004) GEOPSY software. http://www.geopsy.org

Shivkumar K, Maithani PB, Parthasarathy RN et al (1993) Proterozoic rift in lower Champaners and its bearing in uranium mineralisation in Panchmahals district, Gujarat. Abstract in annual convention of Geological Society of India, Organised by Department of Geology. M. S. University of Baroda, Vadodara

Singh AP, Kumar VV, Mishra DC (2004) Subsurface geometry of Hyderabad granite pluton from gravity and magnetic anomalies and its role in the seismicity around Hyderabad. Curr Sci 86:580-586

Singh SB, Ashok Babu G, Veeraiah B et al (2008) Detection of subtrappean sediments by deep resistivity sounding studies in India. In: 7 th international conference and exposition on petroleum geophysics, Hyderabad, pp 106-110

Singh BP, Rao MRK, Prajapati SK et al (2014) Combined gravity and magnetic modeling over Pavagadh and Phenaimata igneous complexes, Gujarat, India: inference on emplacement history of Deccan volcanism. J Asian Earth Sci 80:119-133

Srikarni C, Das S (1996) Stratigraphy and sedimentation history of Champaner Group, Gujarat. J Indian Assoc Sedim 15:93-108

Srimal N, Das S (1998) On the tectonic affinity of the Champaner Group of rocks, eastern Gujarat. Abstract. International seminar on the precambrian crustal evolution of central and eastern India. UNESCO-Lugs-IGCP-368, Bhubaneswar, pp 226-227

Stevenson D, Gangopadhyay A, Talwani P (2006) Booming plutons: source of microearthquakes in South Carolina. Geophys Res Lett 33:L03316

Sukumaran P, Parvez IA, Sant DA et al (2011) Profiling of late Tertiary-early quaternary surface in the lower reaches of Narmada valley using microtremors. J Asian Earth Sci 41:325-334

Vigneresse JL (1990) Use and misuse of geophysical data to determine the shape at depth of granitic intrusions. Geol J 25:249-260

Vigneresse JL (1995) Control of granite emplacement by regional deformation. Tectonophysics 249:173-186

Vigneresse JL, Tikoff B, Ameglio A (1999) Modification of the regional stress field by magma intrusion and formation of tabular granitic plutons. Tectonophysics 302:203-224

Yamanaka H, Takemura M, Ishida H et al (1994) Characteristics of long- period microtremors and their applicability in exploration of deep sedimentary layers. Bull Seismol Soc Am 84:1831-1841

Zhao B, Xie X, Chai C et al (2007) Imaging the graben structure in the deep basin with a microtremor profile crossing the Yinchuan city. J Geophys Eng 4:293-300 